Published in "Forest Policy and Economics", 2019, vol. 102, pp. 100-113, which should be cited to refer to this work.

DOI : $10.1016 / j . f o r p o l .2019 .03 .003$

\title{
A supply-demand modeling of the Swiss roundwood market: Actors responsiveness and $\mathrm{CO}_{2}$ implications
}

\author{
Nicolas Borzykowski*ł
}

28th March 2019

\begin{abstract}
Given the importance of wood products in $\mathrm{CO}_{2}$ sequestration, an increase in the use of local wood in construction may help reduce the sector's net emissions. However, given the low prices of wood, the Swiss forest industry is unwilling to produce more, despite the important potential of wood mobilization. Financial incentives may help meet the goals of both environmental and economic sustainability, if actors respond to price changes. To estimate demand and supply price- and cross-elasticities on the market for roundwood in Switzerland, we use a rich yearly time series data set covering the period 1949-2013. We consider both short term and long term relationships, thanks to a lagged adjustment model and correct for the price endogeneity using a supply-demand equations system estimated with the 3 Stage Least Squares approach. We find that the demand for roundwood is elastic in the long and short run, while the supply is not. However, supply still responds positively to a price increase. In this context, a $10 \%$ increase in the price paid to suppliers would lead to a $5 \%$ increase in Swiss roundwood production. On the demand side, a 10\% decrease in price paid by consumers would lead to a $18 \%$ increase in roundwood consumption. Such an increase in wood uses would lead to sequester $1 \%$ of Swiss $\mathrm{CO}_{2}$ emissions each year.
\end{abstract}

Keywords: Roundwood, Simultaneous equations; Time series; Structural breaks; Construction

JEL classification: Q02, Q21, Q23, C31

*nicolas.borzykowski@hesge.ch: +41 22 3881852

${ }^{\dagger}$ Haute Ecole de Gestion Genève (HEG-Ge), University of Applied Sciences Western Switzerland (HES-SO), 17 rue de la Tambourine, CH-1227 Carouge-Geneva, Switzerland.

${ }^{\ddagger}$ Institute of Economic Research, University of Neuchatel, rue A.-L. Breguet 2, CH-2000 Neuchatel, Switzerland 


\section{Introduction}

Wood is an important resource for the building industry. Indeed, although steel, concrete and cement have substituted timber to a large extent in the last century, the environmental advantage of wood in construction still makes a case in favor of the latter material. Wood sequesters carbon and, if used in buildings, prevents $\mathrm{CO}_{2}$ to spill in the atmosphere (Lippke et al., 2010). In addition, the production of timber requires less energy and wooden buildings are, on average, as energyefficient as concrete buildings. Wooden buildings hence cause fewer emissions throughout their life than buildings made out of other materials such as cement or concrete (Gustavsson et al., 2006). As illustrated in Figure 1, walls in solid wood have a negative $\mathrm{CO}_{2}$ emissions balance. One $\mathrm{m}^{2}$ of solid wood wall is indeed able to sequester $200 \mathrm{~kg}$ of $\mathrm{CO}_{2}$, while its production emits $10 \mathrm{~kg}$ of $\mathrm{CO}_{2}$ only. In comparison, the production of one $\mathrm{m}^{2}$ of concrete wall emits $60 \mathrm{~kg}$ of $\mathrm{CO}_{2}$ and has no carbon storage ability. A more intensive use of wood in construction can therefore be useful as an additional tool to mitigate climate change. In Switzerland, it is thus estimated that substitution of non-wood products by wood products could save a cumulated amount of 110 million tons of CO2 until 2096, based on 2000 levels (FOEN, 2007). This amount corresponds to approximately two years of emissions.

To encourage the use of wood, the Swiss government allows firms to domestically offset their $\mathrm{CO}_{2}$ emissions through wood products (Swiss Federal Council, 2016). In addition, since 2015, norms regarding fires prevention do not limit the use of wood in buildings anymore. These changes engender a renewed interest in the use of wood by the construction sector.

Swiss forests grow in both volume and surface since the $19^{\text {th }}$ century. However, trees get older, which limit their ability to serve as carbon sinks and to adapt to climate change. Given the relative environmental friendliness of wood, the sustainable aspect of an increase in wood production (Borzykowski and Kacprzak, 2019) and the potential of wood mobilization, the Swiss government decided to promote the use of this material within the framework of the Forest Policy 2020 (FOEN, 2013) and the wood resource policy (FOEN, 2008). These strategies indeed target to fully harvest the annual growth of standing wood, i.e. 8.3 million $\mathrm{m}^{3}$ per year, regardless of the assortment or essence. This corresponds to an increase of $70 \%$ compared to the 2013 total harvest.

Yet, the Swiss forest industry suffers from the low price of wood and has not made any profit for decades. Stakeholders thus claim that the current price does not give any incentive for more mobilization (FSO, 2017). Indeed, prices are affected by international markets, where supply is abundant. Given the Swiss restrictive policies regarding the wood harvest and the prevalent high wage levels, international prices often do not cover the production costs.

Given the goal of the Swiss government and the financial bad health of the forest sector, understanding whether the Swiss forest industry responds to price changes is of particular importance. Indeed some doubts emerge regarding the responsiveness of wood market actors to financial incentives. With micro-data at the firm level, Farsi and Krähenbühl (2015) have shown that the Swiss wood supply may not be profit driven but rather only target a given revenue. This result supports the view that financial incentives may be ineffective in increasing the wood production. 




Figure 1: $\mathrm{CO}_{2}$ emissions and sequestration in $\mathrm{kg}$ of $\mathrm{CO}_{2}$ equivalent $/ \mathrm{m}^{2}$ of wall (Source: KBOB, 2009)

Within this context, we use a rich yearly time series data set to estimate demand and supply price- and cross-elasticities on the market for roundwood in Switzerland. The analysis covers the period 1949-2013 and considers both short term and long term relationships, thanks to the Lagged Adjustment model (LAM) (Koyck, 1954). We present an approach that also corrects for the price endogeneity using a supply-demand equations system estimated with 3 Stage Least Squares (3SLS) and deal with structural breaks. In a long time lapse, effects of covariates on the dependent variable can indeed change. Structural breaks are therefore key in modeling long time series data.

Section 2 presents the economic specificities of the Swiss wood market and Section 3 reviews the related literature in developed countries. Section 4 presents our data set and Section 5 explains our econometric approach. Results are available in Section 6. We discuss them and conclude in Section 7.

\section{Economic context}

The Swiss wood market is composed of a multitude of small actors such as forest owners, logging companies, sawmills and end-users, which can be institutional actors, private firms or households and hence respond to different factors. Represented by the two-way arrow in Figure 2, our interest market is comprised between forest owners and wood traders on the supply side and sawmills on the demand side. The demand for roundwood is therefore indirectly driven by the construction sector and marginally by the demand for other wood products.

With the exception of Brännlund (1989), scholars usually consider that markets are competitive (Toppinen and Kuuluvainen, 2010). In this paper, we also adopt this hypothesis. However, one needs to acknowledge that this is a strong simplifying assumption for Switzerland's case. In particular, wood markets are not completely integrated, given the substantial transportation costs. 


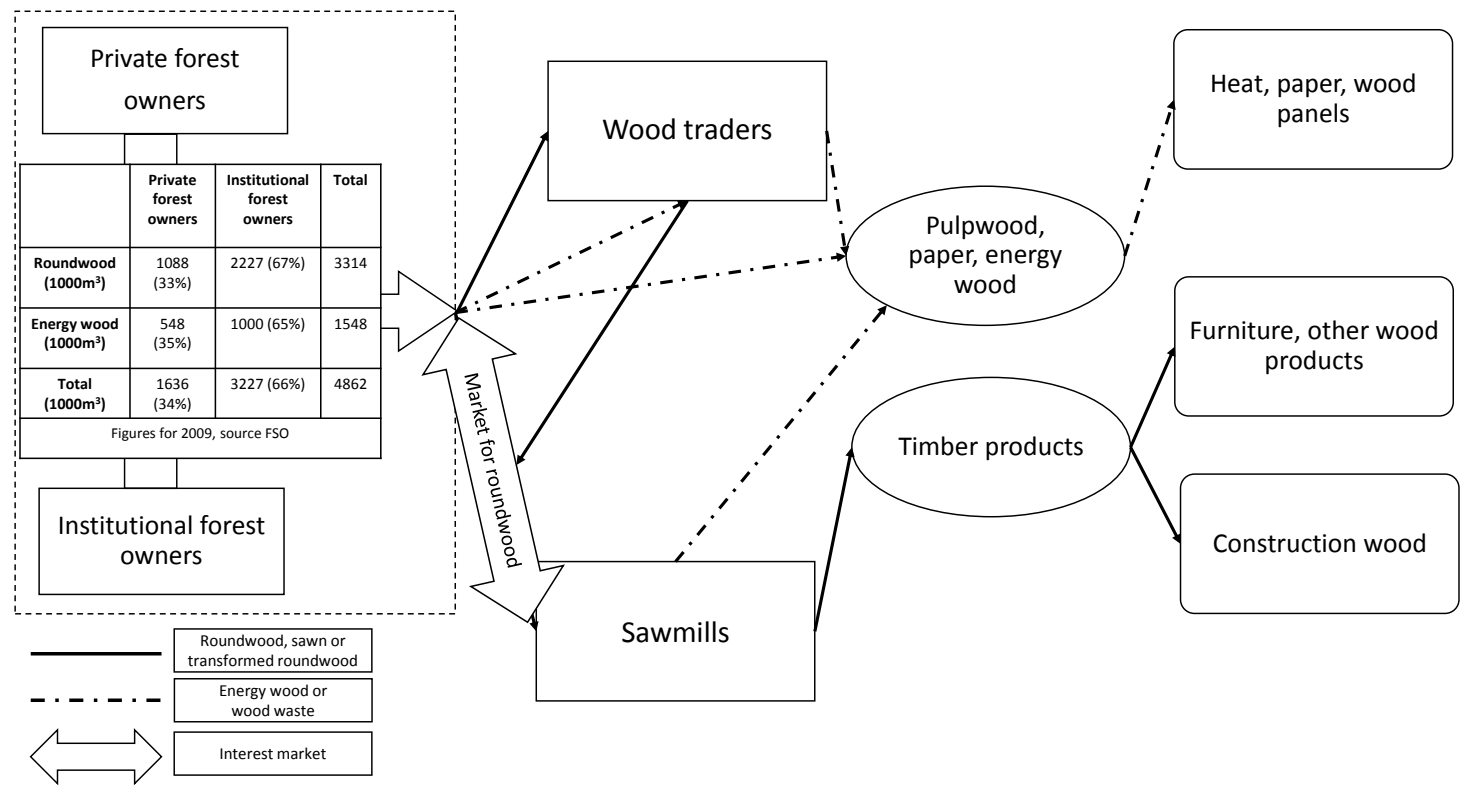

Figure 2: Swiss wood markets in a nutshell (Adapted from Kostadinov et al. 2014)

If they were, the Law of One Price (Richardson, 1978) should hold but some evidence reject it at the world level (Hänninen, 1998), acknowledging the lack of global competition (Kallio, 2001; Olsson, 2009). Olschewski et al. (2015) also suggest that the Swiss wood market is much decentralized as prices are usually bargained over the counter on a case-by-case basis.

From raw wood, a large panel of products can be produced. Differences in wood quality, assortment or essence generate heterogeneous prices (Kostadinov et al., 2014). In addition, there is some complementarity and substitutability among supplied wood products. Indeed, from a particular harvested tree, both energy wood and roundwood can be produced. Wood waste can also be turned into valuable pulp or energy. Therefore, prices of energy wood may have an impact on the production of roundwood. This effect may be positive, if energy wood is a complement to roundwood, or negative if producers substitute roundwood with energy wood. Indeed, the production and storage of roundwood comes with a high cost, requiring caution to extract the wood from the forest, large trucks and appropriate storage places, particularly when a selective harvest is undertaken. This can lead to higher marginal costs for roundwood than for energy wood. Therefore, profit may be higher with the production of energy wood rather than roundwood. Galik et al. (2009) indeed discusses this potential competition.

This substitutability can have an impact on the supply price-elasticities: the higher the substitutability, the higher the price-elasticities. Supply elasticities may also be impacted by production capacities. If production reaches the capacity limits, further increasing the production may become difficult, unless large investments are consented. Therefore, the closer the capacity limit, the lower the elasticities.

On the demand side, price-elasticities magnitude also depend on the availability of substitution alternatives. There exist several potential substitutes to Swiss roundwood such as foreign wood, concrete, bricks or steel. Given the high availability of those products, elasticities are expected to be driven upwards.

Since wood is a storable good, time also plays an important role (Hendel and Nevo, 2004). Entrepreneurs may choose either not to harvest at time $t$ and leave the tree standing until $t+1$ or 
harvest at time $t$ and store until the sales in $t+1$. Consumers may also choose to buy at time $t$ and store until the next period. This may affect the short vs. long term elasticities. However, since adaptation becomes easier with time, entrepreneurs and consumers reactions to a change in price (or in any other factor) should be higher in the long term than in the short term, and hence short term price-elasticities should be lower than long term price-elasticities. This is the Le Chatelier principle, first outlined by Samuelson (1948), which has been confirmed for US forestry markets (See Daigneault et al., 2016, and table 1 hereafter).

Finally, wood supply produces substantial economic externalities. The exploitation of wood indeed affects the different forests functions such as recreational activities, protection against landslides, water and air purification and habitat for biodiversity. On the one hand, a reasonable forest exploitation has positive effects as it secures forest zones and gives more room to particular fauna and flora species. On the other hand, a too intensive exploitation reduces forest's ability to provide its other services (Borzykowski et al., 2017). Given these external effects and the important deficit of forestry since the 90 's, $70 \%$ of forest owners are public entities. Furthermore, forest maintenance can be subsidized, in particular in regions where forest play a protective role.

\section{Literature review}

Time series analyses of wood markets help understand demand and supply's reactions to given factors along time. Buongiorno (1979; 1996), Buongiorno et al. (1988), Brännlund et al. (1985) and Brännlund (1989) extensively studied wood markets in developed countries in the 80's but time series analyses have become less common in Europe in the last decade, as highlighted by Toppinen and Kuuluvainen (2010). A recent renewed interest in this type of approach can be observed by the number of very recent articles on wood products markets (Parajuli and Chang, 2015; Parajuli et al., 2016; Kristöfel et al., 2016; Daigneault et al., 2016; Kinnucan, 2016; Jochem et al., 2016; Sun and Niquidet, 2017; Parajuli and Zhang, 2017, among others). However, most of the studies are based on North American, Chinese (Wan et al., 2010; Zhang et al., 2015, 2017) and Scandinavian data (Mutanen and Toppinen, 2005) and most papers about central Europe focus on energy wood (Kristöfel et al., 2016; Sun and Niquidet, 2017). ${ }^{1}$

With time series on Great Britain, Iriarte-Goñi and Ayuda (2012) analyze the impact of wood use on economic development. These authors first calculate the apparent consumption of wood as the quantity produced minus net exports on the period 1871-1936 and find that the series are trend stationary. They then estimate price and income elasticities with OLS on 3 different periods: according to their results, income elasticity was particularly high $\left(\varepsilon_{I}^{D}=6.23\right)$ during the WW1 and lower $\left(\varepsilon_{I}^{D}=1.22\right)$ before and after that period, wood still being a luxury good during the whole period. With respect to prices, these authors find that the demand for wood was relatively price-elastic during WW1 $\left(\varepsilon_{P}^{D}=-1.5\right)$ and relatively price-inelastic after $\left(\varepsilon_{P}^{D}=-0.49\right)$. They also find an interesting positive cross-relationship with iron, meaning that iron was a substitute to wood in the building and shipbuilding sector.

As reviewed in Daigneault et al. (2016), the literature before the year 2000 finds relatively low short run demand and supply price elasticities of softwood stumpage $\left(\varepsilon_{P}^{D}=-0.001\right.$ to $-0.85 ; \varepsilon_{P}^{S}=$ 0.06 to 0.63 ). We present a review of some price-elasticities found in the post 2010 developed countries literature in Table 1. Both wood product supply and demand elasticities are found to be

\footnotetext{
${ }^{1}$ See Jochem et al. (2016) and Zafeiriou et al. (2012) for analyses of roundwood markets in Germany and Greece, respectively.
} 
below 1, with the exception of wood pellets supply in Austria (Kristöfel et al., 2016). In general, we observe that elasticities are slightly higher in Europe than in the US.

With the same methodology as ours, Daigneault et al. (2016) find inelastic demand and supply on the softwood market between 1950 and 2001. Their results are in line with those of the recent literature. In a study on softwood lumber, Song et al. (2011) estimated a supply-demand system of equations with an Error Correction Model, using US monthly time series data from 1990 to 2006. Their results reveal relatively low demand and supply elasticities $\left(\varepsilon_{P}^{D}=-0.18 ; \varepsilon_{P}^{S}=0.23\right)$. Another interesting result of the latter study is the negative trend on the demand side, meaning that, ceteris paribus, technological progress reduces the demand for wood along time. Parajuli and Chang (2015) also found low price-elasticities on the softwood sawtimber stumpage market. Their result reveal that the market is significantly affected by natural calamities and the 2008 housing crisis. Analyzing a panel of global roundwood markets, Morland et al. (2018) find different supply elasticities: harvests from planted forests react positively but inelastically to price changes, while removals from natural forests do not. The global demand for roundwood products is found to be price-elastic. Tanger and Parajuli (2018) find elastic demand using a 2SLS estimation on a quarterly data set.

There are only a few studies focusing on modeling the Swiss wood markets. ${ }^{2}$ However, to the best of our knowledge, the only time series analysis of roundwood markets in Switzerland is Pauli et al. (2009). These authors regressed the supply on prices, costs, natural disasters and a time trend and the demand on prices, GDP, import prices and storage costs. Their results reveal low supply elasticities but very high demand elasticities (-8.26), which "do not seem realistic" (Pauli et al., 2009, p.84). However, their econometric analysis contains two major drawbacks: first, the price endogeneity is not correctly taken into account and supply and demand are estimated separately via a simple OLS regression. Second, the stationary nature of the series is not discussed, which casts doubts on the reliability of statistical inference from their results.

Table 1: Wood price-elasticities in developed countries in the post 2010 literature

\begin{tabular}{|c|c|c|c|c|c|c|c|}
\hline Study & Wood product & Region & Period & $\varepsilon_{S R}^{D}$ & $\varepsilon_{S R}^{S}$ & $\varepsilon_{L R}^{D}$ & $\varepsilon_{L R}^{S}$ \\
\hline Pauli et al. (2009) & All assortments & Switzerland & $1995-2005$ & & & -8.36 & 0.73 \\
\hline Majumdar et al. (2010) & Softwood lumber & US & 1959-2009 & & & & 0.18 to 0.21 \\
\hline Song et al. (2011) & Softwood lumber & US & $1990-2006$ & -0.14 & 0.16 & -0.18 & 0.23 \\
\hline Zafeiriou et al. (2012) & Roundwood & Greece & $1974-2008$ & & & & 0.97 \\
\hline Parajuli and Chang (2015) & Softwood sawtimber stumpage & Louisiana (US) & $1955-2013$ & -0.38 & & -0.44 & 0.49 \\
\hline Daigneault et al. (2016) & Softwood sawlog & US & $1950-2001$ & -0.08 to -0.18 & 0.15 to 0.26 & -0.24 to -0.48 & \\
\hline Daigneault et al. (2016) & Softwood pulp & US & $1950-2001$ & -0.07 to -0.12 & 0.15 to 0.49 & -0.13 to -0.44 & \\
\hline Kristöfel et al. (2016) & Wood pellets & Austria & $2000-2014$ & & & -0.66 to -0.76 & 1.03 to 1.18 \\
\hline Jochem et al. (2016) & Construction wood & Germany & $1993-2013$ & & & -0.95 & \\
\hline Parajuli and Zhang (2017) & Hardwood sawtimber stumpage & Louisiana (US) & $1955-2014$ & & & -0.85 & 0.73 \\
\hline Morland et al. (2018) & Roundwood from planted forests & World (82 countries) & $2000-2012$ & & 0.23 & & \\
\hline Morland et al. (2018) & Roundwood from natural forests & World ( 82 countries) & 2000-2012 & & n.s. & & \\
\hline Tanger and Parajuli (2018) & Chip-N-Saw softwood stumpage & Louisiana (US) & $2003-2016$ & -1.18 & 0.59 & & \\
\hline
\end{tabular}

\section{Data description}

Our time series analysis covers the period 1949-2013 on a yearly basis. The dependent variable $\left(Q_{t}\right)$ is the quantity of roundwood produced in Switzerland in millions of $\mathrm{m}^{3}$. Various data sources have been used and hence different assumption had to be made to make series consistent. ${ }^{3} Q_{t}$

\footnotetext{
${ }^{2}$ See, for example, Holm et al. (2018) for an agent-based model.

${ }^{3}$ Data sources, units and variables description are available in Table A.1, in the Appendix. A technical notice on how the data were collected is available upon request.
} 
corresponds to roundwood and industrial wood for construction purposes and a marginal part of $Q_{t}$ is also used for the production of furniture. We assume that the market clearing condition is fulfilled, such that $Q_{t}$ is the same on the demand side as well as on the supply side.

We consider different covariates, presented in Table 2, constrained by data availability:

$P_{t}$ : The volume-weighted average real price of wood for construction purposes in $2011 \mathrm{CHF} / \mathrm{m}^{3}$. ${ }^{4}$ Given the lack of consistent data, aggregation and weighted averages had to be used. In general, those prices correspond to wood sold at the closest railway station or at the exit of the forest, free on board. This variable enters both supply and demand equations. We expect it to take a negative sign on the demand side and a positive sign in the supply side, in line with classical economic theory.

Psubs $_{t}$ : The average real import price of steel, iron and other metallic materials in $2011 \mathrm{CHF} / \mathrm{kg} .{ }^{5}$ We use this variable as an indicator for the price of a substitute in the building industry. If steel is indeed a substitute of wood, we expect the coefficient associated with this variable to be positive.

$P x_{t}$ : An index of volume-weighted average production real prices of raw wood from all assortments and essence from publicly owned forests in Germany (DESTATIS, 2017) $(100=2011)$. This exogenous index is likely to proxy the price of foreign wood in Switzerland, since Germany is the biggest exporter of wood in Switzerland (about $45 \%$ of the value of all imported wood products come from Germany in 2013, followed by Italy with 11\% (FOEN,2013)). This variable accounts for the exchange rates differentials by multiplying the raw data by an index of exchange rates between Germany and Switzerland (Swiss National Bank, 2017).

Investment $_{t}$ : The real amount invested in construction in Switzerland in billions of 2011CHF. We use it as an indicator of the economic health in the building sector and of general business cycles. It enters the demand side and is expected to come with a positive coefficient.

Wage in forestryt: The real wage paid to the logging crew in Switzerland in $2011 \mathrm{CHF} / \mathrm{hour}$ (Niederer and Bill, 2015). We use this variable as an indicator of the cost of labor, the main input in the logging industry. We expect that this variable will have a positive impact on the marginal cost and thus a negative impact on the supplied quantity.

$i_{t}$ : The real average interest rate on savings in $\%$. This variable is used to account for the cost of capital. As in the case of the wage, we expect that this variable will have a positive impact on the marginal cost and thus a negative impact on the supplied quantity. ${ }^{6}$

Penergy $y_{t}$ The volume-weighted average real price of energy wood in $2011 \mathrm{CHF} / \mathrm{m}^{3}{ }^{7}$ Again, given the lack of consistent data, aggregation and weighted averages had to be used. In general, those prices correspond to wood sold at the closest railway station or at the exit of the forest, free on board. We use this variable to test whether energy wood is a production substitute or complement to construction wood. We formulate no a priori assumption on the sign of

\footnotetext{
${ }^{4}$ Prices were deflated thanks to the consumer price index (Source: Federal Statistical Office).

${ }^{5}$ Given the nature of data, it is not possible to weight the average according to the volume of each specific commodity.

${ }^{6}$ It is worth noting that the user cost of capital would be a better measure for this variable, since it also includes the depreciation rate. However, to the best of our knowledge, this variable is not available for Switzerland so far in time.

${ }^{7}$ Prices were again deflated thanks to the consumer price index (Source: FSO).
} 
Table 2: Descriptive statistics

\begin{tabular}{llcccc}
\hline & Variable & Mean & Std. Dev. & Min & Max \\
\hline Quantity of roundwood $\left(1000 \mathrm{~m}^{3}\right)$ & $Q_{t}$ & 3.25 & 0.92 & 1.74 & 7.61 \\
Price of roundwood $\left(2011 \mathrm{CHF} / \mathrm{m}^{3}\right)$ & $P_{t}$ & 254.46 & 143.81 & 71.17 & 498.74 \\
Price of substitutes $(2011 \mathrm{CHF} / \mathrm{kg})$ & Psubs $_{t}$ & 1.69 & 0.58 & 0.87 & 3.13 \\
German price $(100=2011)$ & P $_{t}$ & 75.22 & 16.84 & 31.52 & 111.40 \\
Investment in construction $\left(10^{9} 2011 \mathrm{CHF}\right)$ & Investment $_{t}$ & 39.54 & 14.68 & 7.69 & 61.88 \\
Cost of labor $(2011 \mathrm{CHF} / \mathrm{hour})$ & Wage in forestry & 15.14 & 10.57 & 1.96 & 32.53 \\
Cost of capital $(\%)$ & $i_{t}$ & 6.47 & 4.25 & 0.20 & 11.97 \\
Price of energy wood $\left(2011 \mathrm{CHF} / \mathrm{m}^{3}\right)$ & Penergyt & 102.98 & 36.96 & 57.56 & 186.87 \\
Fallen wood $\left(10^{6} \mathrm{~m}^{3}\right)$ & Storm & 0.38 & 1.86 & 0 & 13.98 \\
\hline
\end{tabular}

this variable coefficient. Indeed, as wood can be either transformed into construction or energy wood, there are some substitution possibilities on the production side. However, the production of construction wood also causes wooden waste, which can only be used as energy provider. Therefore, energy wood and construction wood can be complementary as well as substitutes in production.

$S_{\text {torm }}$ : The volume of fallen wood due to major natural calamities in millions of $m^{3}$ (Usbeck, 2015). Two main events can be noted: Vivian, a major storm that happened in 1990, and Lothar, which happened in December 1999 but whose effects were observable in 2000. These storms destroyed large parcels of forests. It is estimated that 10 million trees (13 million $\mathrm{m}^{3}$ (FOEN, 2009)) fell because of Lothar. In 2000, the Swiss government decided to subsidize the forest industry in order to extract fallen trees from forests, which certainly had an impact on the supplied quantity.

$T_{t}$ : A time trend that takes into account technological or preferences changes.

We do not include any indicator of household income because the demand is only indirectly driven by households. Investment in construction is probably a better driver of the demand for timber and mostly arises from firms or the public sector. The latter variable is also correlated with Gross Domestic Product (corr. $=0.88)$.

Figure 3 shows both endogenous series, namely the quantity of roundwood $\left(Q_{t}\right)$ and its associated price $\left(P_{t}\right)$ (not log-transformed). The quantity produced increased from the beginning of the interest period but has started declining after 2008, reaching its lowest level since 1976 in 2013. We observe 2 main peaks: Vivian in 1990 and Lothar in 2000. These storms and the subsidies that followed Lothar increased the production of wood by roughly $44 \%$ for Vivian and $103 \%$ for Lothar (FOEN, 2009). From 1949 to 2013, the production of construction wood has increased by $44 \%$.

The real price of timber remained high until the mid 60's and started declining after that. In 2013, it is $70 \%$ lower than in 1949 but has stabilized after 2000.

Figure 4 shows the evolution of our independent variables (not-log-transformed) for our period of interest. The real price of steel decreased since the beginning of the period until the 2000's. We then observe a slight rebound. The price of wood in Germany has been increasing over the whole period but there are some periods of slower growth from 1955 to 1965, 1980 to 2000 and 2005 to 2013. The economic crisis of the mid-70's caused by the oil shock caused a decrease of investment 




Figure 3: Quantity $\left(Q_{t}\right)$ and real price $\left(P_{t}\right)$ of roundwood produced in Switzerland

in construction, similarly to the burst of the Swiss housing bubble in the beginning of the 90's. This is visible in the third graph. According to the fourth graph, wages in forestry increase on the entire period, following Switzerland real economic growth. The price of energy wood has decreased until 2000 and started increasing slowly since, as shown in the sixth graph. On the last graph, three peaks of fallen wood are clearly observable and correspond to the three strongest storms in 1967, 1990 (Vivian) and 2000 (Lothar).

\section{Econometric approach}

Analyzing the whole market, it is important to deal with the issue of endogeneity. Indeed, at the equilibrium, prices and quantities are simultaneously determined by both demand and supply. Therefore, a system of simultaneous equations, accommodating both sides of the market, is necessary to instrumentalize the endogenous variables. This model can then be estimated using a Two Stage Least Squares (2SLS) or 3SLS approach. Oppositely to 2SLS, 3SLS assumes that error terms of the equations system are correlated. 3SLS is usually more efficient for this kind of model and thus preferred in our case (AlDakhil, 1998). However, the main drawback of 3SLS is its sensitivity to misspecification (Hausman, 1978).

The use of Ordinary Least Squares (OLS) in a time series context is usually not recommended if series are not stationary. Indeed the non-stationary nature of series leads to the problem of spurious regressions and thus to unreliable statistical inference (Granger and Newbold, 1974). We thus observe two different types of model in the literature: variants of the Error Correction Model 

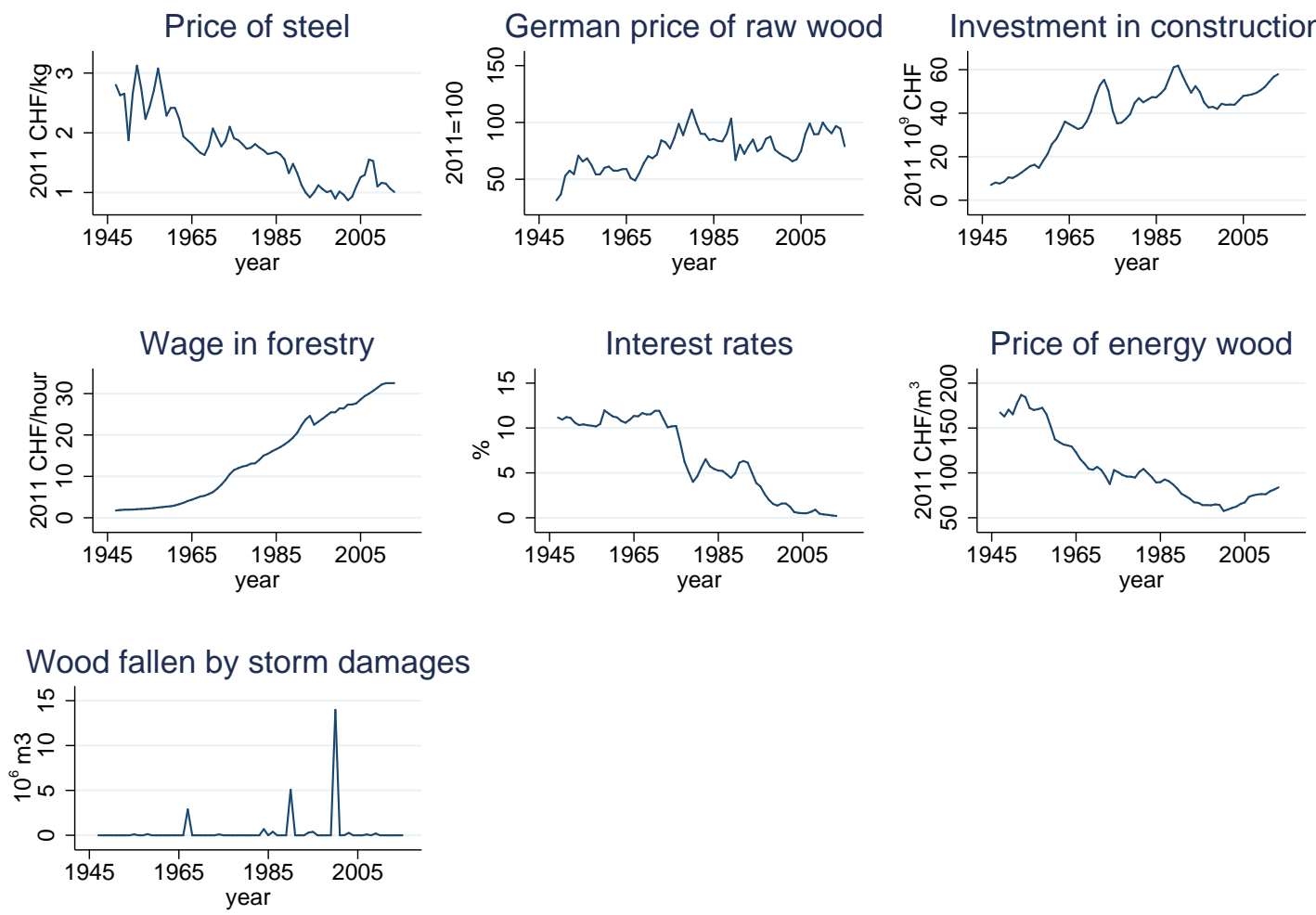

Figure 4: Annual time series

(ECM) developed by Engle and Granger (1987) or the Lagged Adjustment Model (LAM) also called distributed lag model (Koyck, 1954; Jorgenson, 1966; Houthakker and Taylor, 1970) with simultaneous equations. ${ }^{8}$ Hsiao (1997a; 1997b) have indeed demonstrated that the 2SLS and 3SLS estimators are consistent with cointegrated time series $^{9}$ and that one may not worry about nonstationnarity in a dynamic simultaneous equation context, as far as the estimation residuals are stationary (Hsiao and Fujiki, 1998). ${ }^{10}$ In this case, short run and long run variable impacts can be inferred straightforwardly from the estimations and their linear transformation (see Hsiao and Fujiki, 1998, p. 69). Parajuli et al. (2016), studying the sawtimber market in Louisiana, have also shown that both methods lead to similar results in terms of elasticities. In this paper, we thus follow Polyakov et al. (2005), Mutanen and Toppinen (2005) and Daigneault et al. (2016) and estimate a LAM on a simultaneous dynamic demand-supply equations system using 3SLS.

We tested up to 4 lags of the dependent (DV) and independent variables (IDV) on both supply and demand sides of the model and compute the Bayes information criteria (BIC) for each estimated model. This procedure allows selecting the optimal specification. The BIC selects the model with no lagged IDV but a single lagged DV. Hence the best model contains a single lagged DV $\left(Q_{t-1}\right)$. This specification corresponds to the standard geometric lag function (Koyck, 1954),

${ }^{8}$ Studies using the ECM include Song et al. (2011); Parajuli and Chang (2015); Parajuli et al. (2016); Parajuli and Zhang (2017) and LAM Polyakov et al. (2005); Mutanen and Toppinen (2005); Daigneault et al. (2016)

${ }^{9}$ The current and lagged variables being trivially cointegrated (Hsiao, 1997b)

${ }^{10}$ Although stationarity tests are not relevant in a dynamic simultaneous equation context (Hsiao, 1997a), we tested all series with Augmented Dickey-Fuller (Dickey and Fuller, 1979), Philips-Perron (Phillips and Perron, 1988) and KPSS (Kwiatkowski et al., 1992) tests and found that all series are non-stationary on levels but stationary on first differences. Results of these tests are available in Table A.2, in the Appendix. 
which assumes that the effects of lagged IDV decrease with a geometric pattern. The short run effect of a given variable thus correspond to its immediate effect at time $t$, while the long-run effect is the addition of the IDV lags on the whole period. The optimization procedure also recommend adding the lagged DV on the supply side only, because the inclusion of this variable on the demand side increases the BIC. In this paper, we follow the optimization procedure recommendations and add a single lagged IDV on the supply side only. This specification thus assumes that long term and short term elasticities are equal on the demand side (i.e. the demand adjusts immediately), but different on the supply side. The model thus also allows understanding the supply adjustment speed. $^{11} ; 12$

Since our time series cover a long period of time, a number of structural breaks (SB) are expected (Toppinen and Kuuluvainen, 2010). We thus cautiously study structural breaks using a supremum Wald test ${ }^{13}$ on the univariate regression $Q_{t}=\alpha+\beta P_{t}+\epsilon_{t}$ and using Gregory and Hansen (1996) approach (ghansen) $)^{14 ;} \cdot{ }^{15}$

The supremum Wald test identifies a break in 1962. Except for the statistical reason, the year 1962 is marked by the adoption in the Swiss Constitution of the article on nature and landscape protection, which may have had an impact on the forest harvesting policy.

The ghansen approach identifies other breaks ${ }^{16}$ : level breaks in 1991 and 2001 that correspond to the storms Vivian and Lothar respectively and a regime break in 1994. The fact that storms produce structural breaks is not a surprise. However, our results tend to contradict the findings of Kinnucan (2016) that natural disasters cause a regime break (i.e. a rotation in the curves), since, in our case, the tests indicate a shift in levels only. Interestingly, the 1994 regime break follows the adoption of the Swiss forest law, which restricted the wood harvest, by, among other measures, forbidding clear cuts.

While level breaks are relatively easy to handle with a dummy, regime breaks are more difficult in a simultaneous equation context. As the price variable is endogenous, each regime break of price must come with its own instruments. The lack of appropriate additional variable in our data set and the low number of degrees of freedom thus constrain the possibilities to account for regime breaks. In addition, post-estimation tests for the instruments' strength are not available with more than one endogenous variable. We thus choose to only allow for a single regime break on the effect of price. For that purpose, we split the price variable in two, with the cut-off point in 1994, as suggested by the ghansen test. To take the level breaks into account, we add the dummy variables $D 1962_{t}$ and $D 2000_{t}$, which take the value 1 for all years after 1962 and 2000 respectively. We do not account for the 1991 level break, since it came with non-significant coefficients in every tested model.

\footnotetext{
${ }^{11}$ In the Appendix, we also provide results of a model with lags on both the demand and supply sides in Table A.3 and its relative long run elasticities in Table A.4. This model gives no different results from the model recommended by the optimization procedure. Moreover, the demand side lagged variable comes with a non-significant coefficient.

${ }^{12}$ Testing the residuals of the chosen model with a cumulative periodogram white-noise test (Bartlett, 1955), we do not reject that residuals are white noises, revealing no serious problem of auto-correlation. (Prob $>B=0.06$ for the demand and Prob $>B=0.33$ for the supply, with $B$ the Barltett's statistic. Adding up to 4 lagged DV on the demand side does not increase the probability Prob $>B$ ).

${ }^{13}$ This command is provided by the estat sbsingle command on Stata14.

${ }^{14}$ This command is provided by the ghansen command on Stata14.

${ }^{15} \mathrm{~A}$ series of tests for structural breaks exist in the literature. Among other types of tests, the cumulative sum of recursive residuals could be used. Extending further this paper could require to use different tests for structural breaks and compare the results.

${ }^{16} \mathrm{It}$ is worth mentioning that all tests of cointegration provided by the ghansen test reject the null hypothesis of no cointegration.
} 
We add a time trend on the demand side, which accounts for preferences changes or technical progress in the construction sector. We do not include such a variable on the supply side, since its coefficient came insignificant in all tested models and to avoid issues related with overidentification. Furthermore, adding a time trend on the supply side does not change the other coefficients.

We therefore end up with the following models without structural breaks (equation 1) and with structural breaks (equation 2):

$$
\left\{\begin{array}{l}
Q_{t}^{D}=\alpha^{D}+\beta_{1}^{D} P_{t}+\beta_{2}^{D} \text { Psubs }_{t}+\beta_{3}^{D} P x_{t}+\beta_{4}^{D} \text { Investment }_{t}+\beta_{5}^{D} T_{t}+z_{t}^{D} \\
Q_{t}^{S}=\alpha^{S}+\beta_{1}^{S} P_{t}+\beta_{2}^{S} \text { Wage in forestry }{ }_{t}+\beta_{3}^{S} i_{t}+\beta_{4}^{S} \text { Penergy }_{t}+\beta_{5}^{S} \text { Storm }_{t}+\beta_{6}^{S} Q_{t-1}^{S}+z_{t}^{S}
\end{array}\right.
$$

and

$$
\left\{\begin{aligned}
Q_{t}^{D}= & \alpha^{D_{S B}}+\beta_{1}^{D_{S B}} P 1949-1994_{t}+\beta_{2}^{D_{S B}} P 1994-2013_{t}+\beta_{3}^{D_{S B}} \text { Psubs }_{t}+\beta_{4}^{D_{S B}} P_{x_{t}} \\
& +\beta_{5}^{D_{S B}} \text { Investment }{ }_{t}+\beta_{6}^{D_{S B}} T_{t}+z_{t}^{D_{S B}} \\
Q_{t}^{S}= & \alpha^{S_{S B}}+\beta_{1}^{S_{S B}} P 1949-1994_{t}+\beta_{2}^{S_{S B}} P 1994-2013_{t}+\beta_{3}^{S_{S B}} \text { Wage in forestry } y_{t}+\beta_{4}^{S_{S B}} i_{t} \\
& +\beta_{5}^{S_{S B}} \text { Penergy } y_{t}+\beta_{6}^{S_{S B}} \text { Storm }_{t}+\beta_{7}^{S_{S B}} D 1962_{t}+\beta_{8}^{S_{S B}} D 2000_{t}+\beta_{9}^{S_{S B}} Q_{t-1}^{S}+z_{t}^{S_{S B}}
\end{aligned}\right.
$$

With the exception of $i_{t}$, Storm ${ }_{t}$, the trend and the dummies, ${ }^{17}$ we transform all variables in the natural logarithm form.

\section{$6 \quad$ Results}

We present the estimation results of equations 1 and 2, respectively without and with structural breaks in column (1) and (2) of Table 3. All coefficients except Storm $m_{t}$ and $i_{t}$ can be directly interpreted as short run (SR) elasticities.

Coefficients in Table 3 all have the appropriate signs on the demand side estimation. In particular, we observe that the SR price-elasticity of demand is negative. The magnitude of this effect is 1.9 in absolute value and indicates that the demand for construction wood is price-elastic. The addition of regime breaks does not result in any statistically significant change in slope, as shown by model (2). A $1 \%$ increase in price should therefore lead to a 1.8 to $1.9 \%$ decrease in demanded quantity in the short run.

As expected, the cross-elasticity between construction wood and steel is positive. Steel is thus a substitute to wood in the construction sector. Indeed, if the price of steel increases, the latter becomes less attractive, which causes an increased demand for construction wood of $0.9 \%$ for a $1 \%$ increase in steel prices. The German price of wood correlates positively with the demanded quantity. Indeed, if foreign prices increase by $1 \%$, the Swiss wood becomes relatively more attractive and the demanded quantity increases by $0.4 \%$. Investment in construction also has a positive impact on the demand, which is an expected result. For the latter variable, a $1 \%$ increase in investments comes with a $1 \%$ increase in wood consumption. Finally, similarly to Song et al. (2011), we observe a negative trend. That may mean that, thanks to technological changes, construction became more efficient in using wood or that preferences changes have diminished the attractiveness of wood with time.

On the supply side, we observe a positive but relatively small SR price-elasticity between 0.3 and 0.4, which indicates a price-inelastic supply. Again, structural breaks do not result in any significant changes in slope, which tends to show that the adoption of the Swiss law on forest did not significantly affect the supply responsiveness to prices. The price of energy wood negatively

\footnotetext{
${ }^{17}$ As Storm $_{t}$ contains many 0, a log-transformation would cause an important loss of observations. Also a logarithmic transformation is not suitable for percentage variables such as $i_{t}$.
} 
Table 3: Results of the lagged adjustment model estimation

\begin{tabular}{|c|c|c|c|}
\hline & (1) & $(2)$ \\
\hline & & SR relationships & SR relationships \\
\hline & & No breaks & With breaks \\
\hline \multirow{14}{*}{ 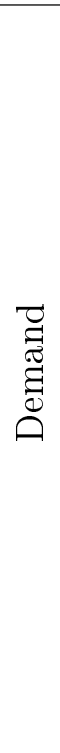 } & $P_{t}$ & $\begin{array}{c}-1.89 * * * \\
(0.44)\end{array}$ & \\
\hline & $P_{t}(1949-1994)$ & & $\begin{array}{c}-1.85 * * * \\
(0.42)\end{array}$ \\
\hline & $P_{t}(1994-2013)$ & & $-1.83^{* * *}$ \\
\hline & & & $(0.41)$ \\
\hline & $P_{s u b s}$ & $0.85^{* * *}$ & $0.86^{* * *}$ \\
\hline & & $(0.28)$ & $(0.27)$ \\
\hline & $P x_{t}$ & $0.40^{*}$ & $0.40^{*}$ \\
\hline & & $(0.22)$ & $(0.23)$ \\
\hline & Investment $_{t}$ & $1.00^{* * *}$ & $1.04^{* * *}$ \\
\hline & & $(0.20)$ & $(0.22)$ \\
\hline & $T_{t}$ & $-0.064^{* * *}$ & $-0.065^{* * *}$ \\
\hline & & $(0.017)$ & $(0.017)$ \\
\hline & Constant & $131.90^{* * *}$ & $133.50^{* * *}$ \\
\hline & & $(33.99)$ & $(35.18)$ \\
\hline \multirow{26}{*}{ 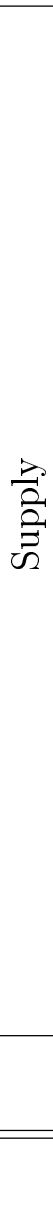 } & $P_{t}$ & $0.28^{* * *}$ & \\
\hline & & $(0.067)$ & \\
\hline & $P_{t}(1949-1994)$ & & $0.41^{* * *}$ \\
\hline & & & $(0.11)$ \\
\hline & $P_{t}(1994-2013)$ & & $0.40 * * *$ \\
\hline & & & $(0.12)$ \\
\hline & Wage in forestryt & $0.11^{* *}$ & $0.18^{* *}$ \\
\hline & & $(0.050)$ & $(0.082)$ \\
\hline & $i_{t}$ & $-0.022^{* *}$ & -0.019 \\
\hline & & $(0.0095)$ & $(0.011)$ \\
\hline & Penergy $_{t}$ & $-0.39 * * *$ & $-0.56 * * *$ \\
\hline & & $(0.13)$ & $(0.18)$ \\
\hline & Storm $_{t}$ & $0.058 * * *$ & $0.057 * * *$ \\
\hline & & $(0.0061)$ & $(0.0067)$ \\
\hline & $D 1962_{t}$ & & $-0.13^{*}$ \\
\hline & & & $(0.068)$ \\
\hline & $D 2000_{t}$ & & $0.093^{*}$ \\
\hline & & & $(0.055)$ \\
\hline & $Q_{t-1}$ & $0.26^{* * *}$ & $0.23^{* * *}$ \\
\hline & & $(0.081)$ & $(0.091)$ \\
\hline & Constant & 1.03 & 1.05 \\
\hline & & $(0.63)$ & $(0.13)$ \\
\hline & Demand Residuals $\mathrm{ADF}^{a}$ & $-4.81^{* *}$ & $-4.96^{* *}$ \\
\hline & Supply Residuals $\mathrm{ADF}^{a}$ & $-6.38 * * *$ & $-5.70 * * *$ \\
\hline & Observations & 64 & 64 \\
\hline & $B I C$ & -99.4 & 84.8 \\
\hline
\end{tabular}

Standard errors in parentheses

$* p<0.1,{ }^{* *} p<0.05,{ }^{* * *} p<0.01$

${ }^{a}$ Augmented Dickey-Fuller test for residuals stationarity (Engle and Yoo, 1987) 
affects the supply of construction wood. This result means that suppliers may have some room to substitute the production of construction wood with energy wood if it becomes more profitable. An increase of $1 \%$ in the price of energy wood leads to a 0.4 to $0.6 \%$ decrease in construction wood production. We also observe a significant positive effect of fallen wood caused by storms. A million $\mathrm{m}^{3}$ of fallen wood comes with an increase of $0.06 \%$ in the construction wood supply. ${ }^{18}$ The effect of the labor cost (Wage in forestry) is surprisingly positive. ${ }^{19}$ This may indicate a problem of reverse causality, since wages in the logging industry may be driven by the logging crew productivity rather than exogenously given. Wages could also temporarily increase due to the need for short term labor when harvest levels are temporarily high. The cost of capital has the expected negative impact. An increase of 1 percentage point in the interest rates leads to a decrease of $0.02 \%$ of the supplied quantity.

The level break in 1962 has an interesting impact. Indeed, years following the adoption of the constitutional law on landscape and nature conservation have a lower intercept, suggesting that this policy has had a negative impact on the output. Daigneault et al. (2016) also found a significant impact of the inclusion of the Northern spotted owl in the Endangered Species list in the US in 1989, which completely stopped the production in some forests.

Contrarily, years following 2000 and the storm Lothar have a higher intercept, probably because of the need to conduct salvage logging and the subsidies that were allocated after the storm Lothar.

In general, given the values of the Bayes Information Criteria $(B I C)$, our preferred model is model (1), without structural breaks. This is not very surprising, since coefficients are similar before and after the breaks.

After estimating the short run relationships, we predict the residuals and test them for stationarity with an Augmented Dickey-Fuller test (ADF). For both models, residuals are found to be stationary, which confirms the cointegration relationship of the series. $^{20}$

It is worth noting that first stage OLS regressions from the 3SLS come with a much higher F-statistic than the usual rule of thumbs of 10 for strong instruments (Staiger and Stock, 1997). Also, the Cragg-Donald F-statistic provided by the ivreg2 command on Stata14, equation by equation, and presented in Table A.5 in the Appendix, show that the maximal IV relative bias is $5 \%$ on the demand side. Moreover, the Anderson canonical correlation statistics presented in the same Table reject the hypothesis that equations are underidentified. However, results from the Sargan statistic for overidentifying restrictions show that our models may be overidentified, but excluding exogenous variables does not affect the Sargan statistic for the demand side.

We observe a significant impact of the lagged quantity variable, which suggests that the supply side adapts over time. Its magnitude is relatively low, indicating relatively quick adjustment. Long run (LR) elasticities must therefore be computed by taking this adjustment into account. This is done by dividing the coefficients by 1 minus the coefficient of the lag variable (see Daigneault et al., 2016). Long run elasticities are presented in Table 4. It is worth reminding that, since we did not include the lagged DV in the demand equation, SR elasticities are equal to LR elasticities on the demand side and are hence not displayed in Table $4 .{ }^{21}$

\footnotetext{
${ }^{18}$ This effect is surprisingly low, given the large impacts of Lothar and Vivian on the production. Indeed, a rough look at the data indicates between 1990 and 2000, the production increased by 3.9 millions $\mathrm{m}^{3}$, while the fallen wood reached 14 millions $\mathrm{m}^{3}$. The expected impact of one $\mathrm{m}^{3}$ of fallen wood would therefore be around 0.28 for the year 2000 and we observe approximately the same expected impact in 1990 and 1967 . However, this coefficients indicates an average effect on the whole period and some relatively small storms may have had no effects on the wood supply. Also, it is possible that part of the effects may be integrated in the $D 2000_{t}$ variable.

${ }^{19}$ The inclusion of a lag gives similar results.

${ }^{20}$ Plots of the residuals are available in Figure A.1 in the Appendix.

${ }^{21}$ Similar results from a model with lags on both the demand and supply sides are presented in Table A.3 and its
} 
Supply long run elasticities are larger than short run elasticities, which confirms Le Chatelier principle that agents have more time to adapt in the long run. However, supply elasticities remain low on the long run as well. The supply price-elasticities resulting from our estimations are in the same order of magnitude as those from recent studies presented in Table 1. In contrast, we find higher price-elasticities on the demand side. This result suggests that the Swiss construction wood can be easily substituted with another material or with imported foreign wood.

As a measurement of the model's precision, we forecast the dependent variable on both the beginning and the end of our interest period and compare it with actual values. The forecasting methodology and the comparisons are presented in the Appendix. They show that more recent years are better predicted than earlier years.

Table 4: Long run supply elasticities

\begin{tabular}{|c|c|c|c|}
\hline & & $(1)$ & $(2)$ \\
\hline & & LR relationships & LR relationships \\
\hline & & No breaks & With breaks \\
\hline & $P_{t}$ & $\begin{array}{c}0.37^{* * *} \\
(0.097)\end{array}$ & \\
\hline & $P_{t}(1949-1994)$ & & $0.53 * * *$ \\
\hline & & & $(0.16)$ \\
\hline & $P_{t}(1994-2013)$ & & $0.53^{* * *}$ \\
\hline & & & $(0.18)$ \\
\hline & Wage in forestryt & $0.14^{* *}$ & $0.23^{* *}$ \\
\hline & & $(0.064)$ & $(0.11)$ \\
\hline ह & $i_{t}$ & $-0.029 * *$ & $-0.024^{*}$ \\
\hline$\stackrel{2}{=}$ & & $(0.013)$ & $(0.015)$ \\
\hline & Penergyt & $-0.53 * * *$ & $-0.73 * * *$ \\
\hline & & $(0.17)$ & $(0.21)$ \\
\hline & Storm $_{t}$ & $0.078 * * *$ & $0.074^{* * *}$ \\
\hline & & $(0.012)$ & $(0.014)$ \\
\hline & $D 1962_{t}$ & & $-0.16^{*}$ \\
\hline & & & $(0.092)$ \\
\hline & $D 2000_{t}$ & & $0.12^{*}$ \\
\hline & & & $(0.069)$ \\
\hline
\end{tabular}

Standard errors in parentheses

${ }^{*} p<0.1,{ }^{* *} p<0.05,{ }^{* * *} p<0.01$

\section{Discussion and conclusion}

The commitment of the Swiss government to encourage the production of Swiss wood and its use in buildings is a step towards a more carbon neutral economy. Achieving this goal requires to mobilize more wood from Swiss forests, what the forest industry is currently unwilling to do given the lack of financial incentives. Encouragements through subsidies would be useful only if suppliers and consumers react to price changes. We analyze the effect of the price on roundwood supply

relative long run elasticities in Table A.4 in the Appendix. The lagged DV has an insignificant coefficient on the demand side. 
and demand thanks to a rich annual time series data set on the period 1949-2013. The use of the Lagged Adjustment Model allows deriving long run and short run elasticities, while correcting for price endogeneity thanks to a simultaneous supply-demand equations system estimated with the 3 Stage Least Squares approach.

Our results are generally in line with the international literature but show that the demand is sensitive to prices changes. This is not very surprising, given the numerous substitutes to Swiss wood in construction. On the other hand, the supply is price-inelastic and its responsiveness, although positive, is lower in the short run than in the long run. This could be explained by steeply increasing marginal costs or by the public ownership of forest zones, since public owners may not only be profit driven.

Natural disasters such as the storm Lothar, caused a positive level shift in 2000 . While the need to conduct salvage logging and easier extraction of fallen wood may explain the specificities of the year 2000, the shift is persistent until the end of the interest period. This long-lasting effect may be explained by the persistence of subsidies, whose importance have been integrated by policy-makers. Another explanation may be that, following Lothar, producers have invested to increase their production capacity, leading to a persistent higher supply.

Other structural breaks in our series correspond to changes in the legal context. Although indispensable, the tight regulation might thus break the Swiss wood provision, leading to forests' ageing. Since old forests are less able to serve as carbon sinks, adapting the Swiss forest management to face the climate change challenges might be necessary. The wood production should thus be financially fostered to fully integrate positive externalities on $\mathrm{CO}_{2}$ sequestration brought by rejuvenation of forests. Given the positive supply responsiveness to prices, a subsidy and an increased demand might indeed help meet the goals of the Forest Policy 2020 and increase the production of Swiss wood. More specifically, a $10 \%$ increase in the price received by suppliers would increase the production by 4 to $5 \%$ in the long run. In addition, financial incentives may increase the use of Swiss wood in construction and thus reduce the $\mathrm{CO}_{2}$ emissions of the sector: on the demand side, a $10 \%$ price decrease would lead to 18 to $19 \%$ more consumption. Compared to the 2013 level, this would allow sparing 500 thousand tons of $\mathrm{CO}_{2}$ emissions each year, $1 \%$ of Switzerland's annual emissions. However, this price increase is likely to be insufficient to reach FOEN (2007) projections, everything else remaining constant. ${ }^{22}$ Acknowledging this fact, the Swiss government has consented large marketing investments aiming at promoting the use of Swiss wood (FOEN, 2017). Consequently, preferences are likely to change in the future.

Finally, given the carbon neutrality of energy wood, the Federal Office for Environment (FOEN, 2008) encourages the use of wood for energy purposes as well. The latter policy may however be counterproductive to increase the production of construction wood. Indeed, our results show that construction wood and energy wood can be substitutes on the supply side. If the demand and thus the price of energy wood increases, suppliers may switch from construction wood to energy wood, the marginal cost of the latter being lower. This would reduce the available Swiss wood quantity and thus increase the $\mathrm{CO}_{2}$ emissions of the construction sector.

This paper and its results have a number of limitations. First, the low number of observations and the difficulty to find reliable historical data reduces the ability to complicate the model. For this reason, we do not consider imperfect competition that may be prevalent on the roundwood market. Our model also imperfectly accounts for international competition and domestic wood and imported wood are thus considered as imperfect substitutes. ${ }^{23}$ Finally, given the lack of consistent

\footnotetext{
${ }^{22}$ The model being only able to model marginal changes, it would be unreasonable to advice for an optimal price change.

${ }^{23}$ This assumption is consistent with the findings of Borzykowski and Kacprzak (2019), which reveals that $55 \%$
} 
data, the storage capacity on the supply, as well as on the demand side, could not be included in the model. In the same spirit, Solow residuals could have been used to account for technological changes (Solow, 1957). However, this would imply an important data collection regarding the construction sector and is beyond the scope of this paper.

The data collection and results from this paper open avenues for new pieces of research. First, analyses of impacts on welfare, in particular the effect of structural breaks, could provide interesting information on the total economic surpluses created by the Swiss wood markets. Second, since data on energy wood had also been collected, one could analyze the energy wood market with the same kind of methodology. Third, a link between the energy wood market and the roundwood market could be studied. Finally, the spatial dimension could also be analyzed with a panel data approach, since cantonal data on wood production are available since $2004 .^{24}$ This would allow confirming our results with less concerns about the time series nature of the data.

\section{Acknowledgments}

I would like to thank Francisco Aguilar, Andrea Baranzini, Serge Garcia, Bengt Kriström, Tim Lloyd, David Maradan, Sylvain Weber and Milad Zarin-Nejadan for the insightful conversations and Thomas Wohlgemuth and Alain Schönenberger for their help with the data. Financial support from the Swiss National Research Program 66 Resource wood is acknowledged. The usual disclaimers apply.

\section{References}

AlDakhil, K. (1998). A method for estimating simultaneous equations models with time-series and cross-section data. Journal of King Saud University-Administrative Sciences, 10(1):13-28.

Bartlett, M. S. (1955). An introduction to stochastic processes: with special reference to methods and applictions. Cambridge Univ. Press.

Borzykowski, N., Baranzini, A., and Maradan, D. (2017). Y a-t-il assez de réserves forestières en Suisse ? Une évaluation contingente. Économie rurale, 359.

Borzykowski, N. and Kacprzak, A. (2019). Interroger les équilibres de la multifonctionnalité dans les forêts helvétiques. Regards croisés d'experts et de la population. Revue Forestière Française, To be published.

Brännlund, R. (1989). The social loss from imperfect competition: The case of the Swedish pulpwood market. The Scandinavian Journal of Economics, pages 689-704.

Brännlund, R., Johansson, P.-O., and Gustaf Löfgren, K. (1985). An econometric analysis of aggregate sawtimber and pulpwood supply in Sweden. Forest Science, 31(3):595-606.

Buongiorno, J. (1979). Income and price elasticities of demand for sawn wood and wood-based panels: a pooled cross-section and time-series analysis. Canadian Journal of Forest Research, 9(2):141-148.

of the Swiss population prefers Swiss wood rather than imported wood.

${ }^{24}$ This would lead to a data set of 26 cantons for 9 years and thus 234 observations. However, independent variables are only available at the national scale. 
Buongiorno, J. (1996). Forest sector modeling: a synthesis of econometrics, mathematical programming, and system dynamics methods. International Journal of Forecasting, 12(3):329-343.

Buongiorno, J., Chavas, J.-P., and Uusivuori, J. (1988). Exchange rates, Canadian lumber imports, and United States prices: a time-series analysis. Canadian Journal of Forest Research, 18(12):1587-1594.

Daigneault, A. J., Sohngen, B., and Kim, S. J. (2016). Estimating welfare effects from supply shocks with dynamic factor demand models. Forest Policy and Economics, 73:41-51.

DESTATIS (2017). Erzeugerpreisindizes der Produkte des Holzeinschlags aus des Staatsforsten. https://www-genesis.destatis.de/genesis/online/data; jsessionid= 22B9F69331D4237EE97C11EABED7DE21.tomcat_G0_1_3?operation=begriff sRecherche\& suchanweisung_language=en\&suchanweisung=61231. Accessed: 31.01.2017.

Dickey, D. A. and Fuller, W. A. (1979). Distribution of the estimators for autoregressive time series with a unit root. Journal of the American Statistical Association, 74(366a):427-431.

Engle, R. F. and Granger, C. W. (1987). Co-integration and error correction: representation, estimation, and testing. Econometrica, pages 251-276.

Engle, R. F. and Yoo, B. S. (1987). Forecasting and testing in co-integrated systems. Journal of Econometrics, 35(1):143-159.

Farsi, M. and Krähenbühl, G. (2015). L'approvisionnement en bois brut dans un marché de concurrence imparfaite. Schweizerische Zeitschrift fur Forstwesen, 166(5):299-305.

FOEN (1991-1996). Wald- und Holzwirtschaft der Schweiz Jahrbuch. Technical report, Federal Office for the Environment.

FOEN (1998-2014). Wald und Holz in der Schweiz Jahrbuch. Technical report, Federal Office for the Environment.

FOEN (2007). The CO2 effects of the Swiss forestry and timber industry: scenarios of future potential for climate-change mitigation. Technical report, Federal Office for the Environment.

FOEN (2008). Politique de la ressource bois: Stratégie, objectifs et plan d'action bois. Technical report, Federal Office for the Environment.

FOEN (2009). 10 ans après Lothar: enseignements tirés pour l'avenir. http://www. bafu .admin . $\mathrm{ch} /$ dokumentation/medieninformation/00962/index.html?lang=fr $\backslash \mathrm{msg}-i d=30489$. Accessed: 05.09.2016.

FOEN (2013). Politique forestière 2020; visions, objectifs et mesures pour une gestion durable des forêts suisses. Technical report, Federal Office for the Environment.

FOEN (2017). WOODVETIA. https ://www . woodvetia.ch/fr/. Accessed: 27.09.2018.

FSO (1908-1976). Statistique forestière suisse. Technical report, Swiss Federal Statistical Office.

FSO (1985-1990). Annuaire suisse de l'économie forestière et de l'industrie du bois. Technical report, Swiss Federal Statistical Office. 
FSO (2015). Statistique et histoire. http://www.bfs.admin.ch/bfs/portal/fr/index/ dienstleistungen/history.html. Accessed: 02.07.2015.

FSO (2017). Statistique forestière suisse 2016: La récolte de bois à son niveau le plus bas depuis 10 ans. https://www.bfs.admin.ch/bfs/fr/home/actualites/quoi-de-neuf. assetdetail.3102900.html. Accessed: 25.08.2018.

Galik, C. S., Abt, R., and Wu, Y. (2009). Forest biomass supply in the Southeastern United States: implications for industrial roundwood and bioenergy production. Journal of Forestry, 107(2):69-77.

Granger, C. W. and Newbold, P. (1974). Spurious regressions in econometrics. Journal of Econometrics, 2(2):111-120.

Gregory, A. W. and Hansen, B. E. (1996). Residual-based tests for cointegration in models with regime shifts. Journal of Econometrics, 70(1):99-126.

Gustavsson, L., Pingoud, K., and Sathre, R. (2006). Carbon dioxide balance of wood substitution: comparing concrete-and wood-framed buildings. Mitigation and Adaptation Strategies for Global Change, 11(3):667-691.

Hänninen, R. H. (1998). The law of one price in United Kingdom soft sawnwood imports-a cointegration approach. Forest Science, 44(1):17-23.

Hausman, J. A. (1978). Specification tests in econometrics. Econometrica, pages 1251-1271.

Hendel, I. and Nevo, A. (2004). Intertemporal substitution and storable products. Journal of the European Economic Association, 2(2-3):536-547.

Holm, S., Thees, O., Lemm, R., Olschewski, R., and Hilty, L. M. (2018). An agent-based model of wood markets: Scenario analysis. Forest Policy and Economics, 95:26-36.

Houthakker, H. S. and Taylor, L. D. (1970). Consumer Demand in the United States. Harvard University Press.

Hsiao, C. (1997a). Cointegration and dynamic simultaneous equations model. Econometrica, pages 647-670.

Hsiao, C. (1997b). Statistical properties of the two-stage least squares estimator under cointegration. Review of Economic Studies, 64(3):385-398.

Hsiao, C. and Fujiki, H. (1998). Nonstationary time-series modeling versus structural equation modeling: With an application to Japanese money demand. Monetary and Economic Studies, $16(1): 57-80$.

Iriarte-Goñi, I. and Ayuda, M.-I. (2012). Not only subterranean forests: Wood consumption and economic development in Britain (1850-1938). Ecological Economics, 77:176-184.

Jochem, D., Janzen, N., and Weimar, H. (2016). Estimation of own and cross price elasticities of demand for wood-based products and associated substitutes in the German construction sector. Journal of Cleaner Production, 137:1216-1227. 
Jorgenson, D. W. (1966). Rational distributed lag functions. Econometrica, pages 135-149.

Kallio, A. M. I. (2001). Analysing the Finnish pulpwood market under alternative hypotheses of competition. Canadian Journal of Forest Research, 31(2):236-245.

KBOB (2009). Données des écobilans dans la construction. https://www.kbob.admin.ch/kbob/ fr/home/publikationen/nachhaltiges-bauen.html. Accessed: 11.11.2016.

Kinnucan, H. W. (2016). Timber price dynamics after a natural disaster: Hurricane Hugo revisited. Journal of Forest Economics, 25:115-129.

Kostadinov, F., Holm, S., Steubing, B., Thees, O., and Lemm, R. (2014). Simulation of a Swiss wood fuel and roundwood market: An explorative study in agent-based modeling. Forest Policy and Economics, 38:105-118.

Koyck, L. M. (1954). Distributed Lags and Investment Analysis. North-Holland Publishing Company Amsterdam.

Kristöfel, C., Strasser, C., Schmid, E., and Morawetz, U. B. (2016). The wood pellet market in Austria: A structural market model analysis. Energy Policy, 88:402-412.

Kwiatkowski, D., Phillips, P. C., Schmidt, P., and Shin, Y. (1992). Testing the null hypothesis of stationarity against the alternative of a unit root: How sure are we that economic time series have a unit root? Journal of Econometrics, 54(1):159-178.

Lippke, B., Wilson, J., Meil, J., and Taylor, A. (2010). Characterizing the importance of carbon stored in wood products. Wood and Fiber Science, 42:5-14.

Lucas, R. E. J. (1972). Expectations and the neutrality of money. Journal of Economic Theory, $4(2): 103-124$.

Majumdar, S., Zhang, D., and Zhang, Y. (2010). Estimating regional softwood lumber supply in the United States using seemingly unrelated regression. Forest Products Journal, 60(7):709-714.

Morland, C., Schier, F., Janzen, N., and Weimar, H. (2018). Supply and demand functions for global wood markets: Specification and plausibility testing of econometric models within the global forest sector. Forest Policy and Economics, 92:92-105.

Mutanen, A. and Toppinen, A. (2005). Finnish sawlog market under forest taxation reform. Silva Fennica, 39(1):117-130.

Niederer, R. and Bill, M. (2015). Entwicklung der Rohholzpreise und der Lohnkosten in der Forstwirtschaft: Eine Zeitreihe von 1919 / 1939 bis 2014. Technical report, Federal Office for the Environment.

Olschewski, R., Schaller, M., Dittgen, A., Lemm, R., Kimmich, C., Markovic, J., and Thees, O. (2015). Marktverhalten öffentlicher Forstbetriebe in Graubünden und im Aargau. Schweizerische Zeitschrift fur Forstwesen, 166(5):282-290.

Olsson, O. (2009). European Bioenergy Markets: Integration and Price Convergence. Department of Energy and Technology, Swedish University of Agricultural Sciences. 
Parajuli, R. and Chang, S. J. (2015). The softwood sawtimber stumpage market in Louisiana: market dynamics, structural break, and vector error correction model. Forest Science, 61(5):904913.

Parajuli, R. and Zhang, D. (2017). An econometric study of the hardwood sawtimber stumpage market in Louisiana. Forest Products Journal, 67(1):91-100.

Parajuli, R., Zhang, D., and Chang, S. J. (2016). Modeling stumpage markets using vector error correction vs. simultaneous equation estimation approach: A case of the Louisiana sawtimber market. Forest Policy and Economics, 70:16-19.

Pauli, B., Thees, O., Bürgi, P., Brülhart, S., Lemm, R., and Rosset, C. (2009). Holz als Rohstoff und Energieträger. Technical report.

Phillips, P. C. and Perron, P. (1988). Testing for a unit root in time series regression. Biometrika, $75(2): 335-346$.

Polyakov, M., Teeter, L. D., and Jackson, J. D. (2005). Econometric analysis of Alabama's pulpwood market. Forest Products Journal, 55(1):41.

Richardson, J. D. (1978). Some empirical evidence on commodity arbitrage and the law of one price. Journal of International Economics, 8(2):341-351.

Samuelson, P. A. (1948). Foundations of Economic Analysis. Harvard University Press.

Siegenthaler, H. and Ritzman-Blickenstorfer, H. (1996). Statistique historique de la Suisse. Technical report, Swiss Federal Statistical Office.

Solow, R. M. (1957). Technical change and the aggregate production function. Review of Economics and Statistics, pages 312-320.

Song, N., Chang, S. J., and Aguilar, F. X. (2011). US softwood lumber demand and supply estimation using cointegration in dynamic equations. Journal of Forest Economics, 17(1):19-33.

Staiger, D. and Stock, J. (1997). Instrumental variables regression with weak instruments. Econometrica, 65(3):557-586.

Stock, J. H. and Yogo, M. (2005). Testing for weak instruments in linear iv regression. Identification and inference for econometric models: Essays in honor of Thomas Rothenberg.

Sun, L. and Niquidet, K. (2017). Elasticity of import demand for wood pellets by the European Union. Forest Policy and Economics.

Swiss Federal Council (2016). Ordinance on the reduction of CO2 emissions. https : / www . admin . ch/opc/en/classified-compilation/20120090/index.html. Accessed: 25.08.2016.

Swiss National Bank (2017). Portail de données de la Banque nationale suisse. https://data. snb.ch/fr. Accessed: 14.06.2017.

Tanger, S. M. and Parajuli, R. (2018). Toward an elasticity of chip-n-saw: Demand and supply models of chip-N-saw stumpage in Louisiana. Forests, 9(4):211. 
Toppinen, A. and Kuuluvainen, J. (2010). Forest sector modelling in Europe: the state of the art and future research directions. Forest Policy and Economics, 12(1):2-8.

Usbeck, T. (2015). Wintersturmschäden im Schweizer Wald von 1865 bis 2014. Schweizerische Zeitschrift fur Forstwesen, 166(3):184-190.

Wan, M., Toppinen, A., and Hänninen, R. (2010). Econometric analysis of China's plywood market. Forest Products Journal, 60(7):679-687.

Zafeiriou, E., Arabatzis, G., and Koutroumanidis, T. (2012). The round wood market in Greece: An empirical approach. Forest Systems, 21(1):31-41.

Zhang, H., Kuuluvainen, J., Lin, Y., Gao, P., and Yang, H. (2017). Cointegration in China's log import demand: Price endogeneity and structural change. Journal of Forest Economics, 27:99-109.

Zhang, H., Zhao, Q., Kuuluvainen, J., Wang, C., and Li, S. (2015). Determinants of China's lumber import: A bounds test for cointegration with monthly data. Journal of Forest Economics, 21(4):269-282. 


\section{Appendix}

Table A.1: Data sources, units and description

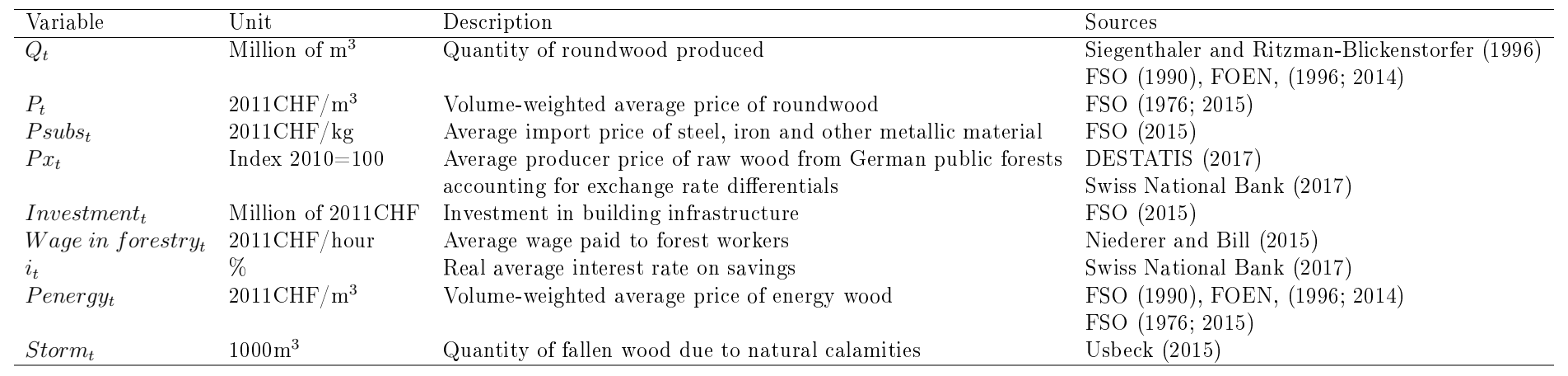


Table A.2: Stationarity tests

\begin{tabular}{|c|c|c|c|c|c|c|c|c|c|}
\hline \multirow[t]{2}{*}{ Variable } & \multicolumn{3}{|c|}{ ADF } & \multicolumn{3}{|c|}{ Phillips-Perron } & \multicolumn{3}{|c|}{ KPSS } \\
\hline & $Z_{t}$ & lags & form & $Z_{\rho}$ & lags & form & $\eta$ & lags & form \\
\hline$Q_{t}$ & -0.88 & 2 & no $t$ & $-11.01^{*}$ & 2 & no t & $0.97^{* * *}$ & 5 & no $t$ \\
\hline$\Delta Q_{t}$ & $-7.78^{* * *}$ & 1 & no $t$ & $-81.50 * * *$ & 1 & no t & 0.25 & 5 & no $t$ \\
\hline$P_{t}$ & -1.62 & 0 & $\mathrm{t}$ & -10.50 & 0 & $\mathrm{t}$ & $0.18^{* *}$ & 6 & $\mathrm{t}$ \\
\hline$\Delta P_{t}$ & $-7.05^{* * *}$ & 1 & $\mathrm{t}$ & $-57.82^{* * *}$ & 1 & $\mathrm{t}$ & $0.16^{* *}$ & 8 & $\mathrm{t}$ \\
\hline Psubs $_{t}$ & -0.41 & 1 & no $t$ & -4.13 & 1 & no t & $1.03^{* * *}$ & 5 & no $t$ \\
\hline$\Delta P s u b s_{t}$ & $-2.80^{* * *}$ & 1 & no $t$ & $-68.26^{* * *}$ & 1 & no t & 0.07 & 8 & no $t$ \\
\hline$P x_{t}$ & -2.14 & 0 & $\mathrm{t}$ & -13.68 & 0 & $\mathrm{t}$ & $0.17^{* *}$ & 5 & $\mathrm{t}$ \\
\hline$\Delta P x_{t}$ & $-7.74^{* * *}$ & 0 & $\mathrm{t}$ & $-66.24^{* * *}$ & 0 & $\mathrm{t}$ & 0.08 & 5 & $\mathrm{t}$ \\
\hline Investment $_{t}$ & -1.37 & 1 & $\mathrm{t}$ & -5.51 & 1 & $\mathrm{t}$ & $0.26^{* * *}$ & 5 & $\mathrm{t}$ \\
\hline$\Delta$ Investment $_{t}$ & $-4.61^{* * *}$ & 1 & $\mathrm{t}$ & $-36.48^{* * *}$ & 1 & $\mathrm{t}$ & 0.12 & 5 & $\mathrm{t}$ \\
\hline Wage in forestryt & -0.78 & 1 & $\mathrm{t}$ & 0.93 & 1 & $\mathrm{t}$ & $0.27 * * *$ & 5 & $\mathrm{t}$ \\
\hline$\Delta W$ age in forestryt & $-3.56^{* *}$ & 0 & $\mathrm{t}$ & $-27.58^{* * *}$ & 0 & $\mathrm{t}$ & $0.15^{* *}$ & 5 & $\mathrm{t}$ \\
\hline$i_{t}$ & -0.31 & 2 & no $t$ & -0.65 & 2 & no t & $1.09 * * *$ & 5 & no t \\
\hline$\Delta i_{t}$ & $-5.27 * * *$ & 1 & no $t$ & $-36.40^{* * *}$ & 1 & no t & 0.09 & 4 & no $t$ \\
\hline Penergy $_{t}$ & -0.63 & 0 & no $t$ & -4.06 & 0 & no t & $0.90^{* * *}$ & 6 & no $t$ \\
\hline$\Delta$ Penergyt & $-3.38 * * *$ & 0 & no $t$ & $-64.21 * * *$ & 0 & no t & $0.36^{*}$ & 4 & no $t$ \\
\hline Storm $_{t}$ & $-8.16^{* * *}$ & 0 & no $t$ & $-66.71^{* * *}$ & 0 & no t & 0.22 & 6 & no $t$ \\
\hline$\Delta$ Storm $_{t}$ & $-13.65^{* * *}$ & 0 & no $t$ & $-64.21^{* * *}$ & 0 & no $t$ & 0.04 & 4 & no $t$ \\
\hline
\end{tabular}

${ }^{* * *} \mathrm{p}<0.01,{ }^{* *} \mathrm{p}<0.05,{ }^{*} \mathrm{p}<0.1$

$\mathrm{t}$ : trend, no t: no trend

For augmented Dickey-Fuller tests (ADF) (Dickey and Fuller, 1979) and Phillips-Perron tests (Phillips and Perron, 1988), lags and functional forms have been chosen thanks to the Bayesian Information criteria. H0: The series is non-stationary For KPSS (Kwiatkowski et al., 1992) test, the number of lags was selected by automatic bandwidth selection and autocovariances weighted by Bartlett Kernel. H0: The series is stationary 
Table A.3: Results of the lagged adjustment model estimation with lags on both side

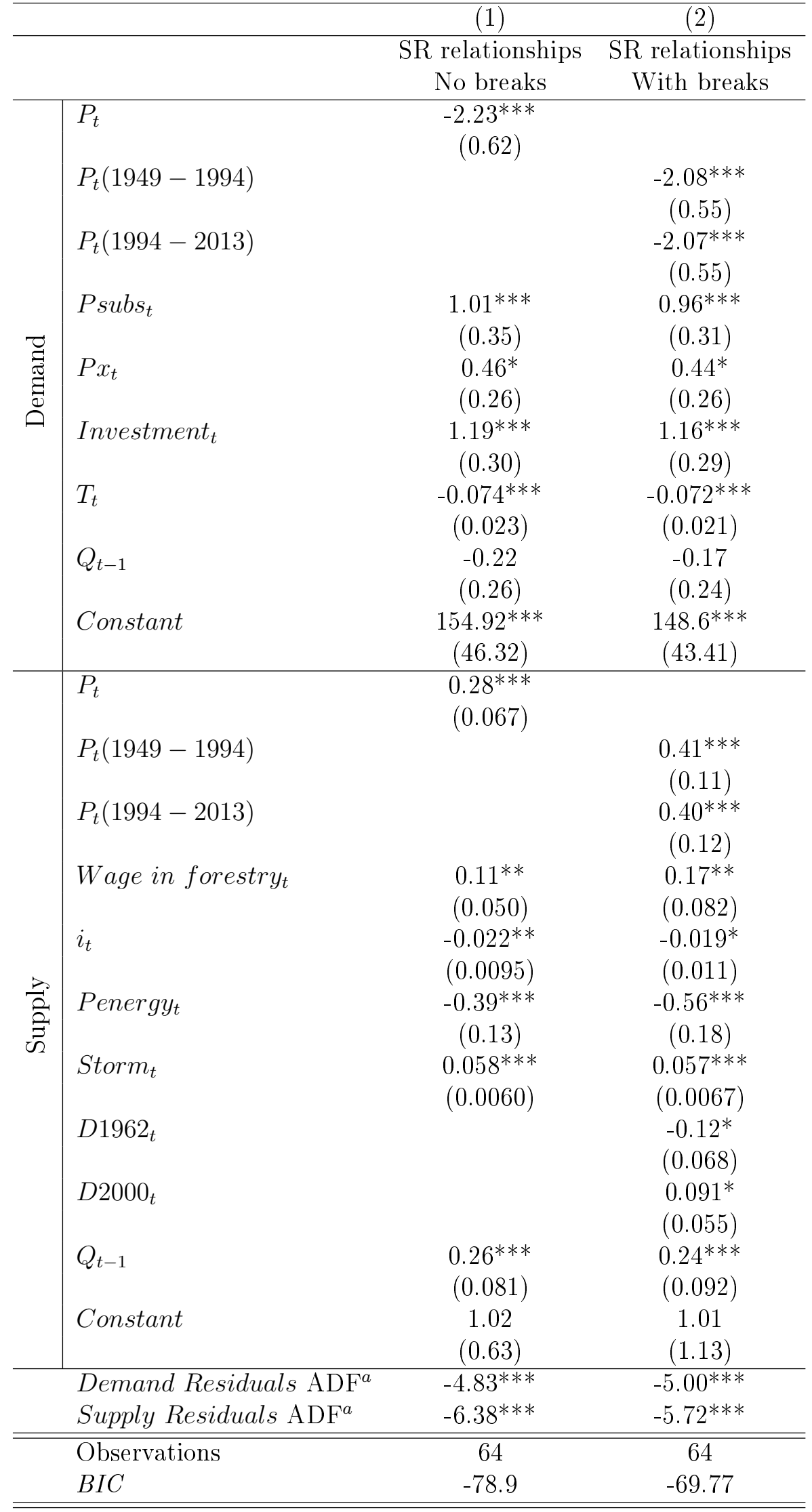

Standard errors in parentheses

${ }^{*} p<0.1,{ }^{* *} p<0.05,{ }^{* * *} p<0.01$

${ }^{a}$ Augmented Dickey-Fuller test for residuals stationarity (Engle and Yoo, 1987) 
Table A.4: Long run elasticities based on the model with lags on both sides

\begin{tabular}{|c|c|c|c|}
\hline & & (1) & $(2)$ \\
\hline & & LR relationships & LR relationships \\
\hline & & No breaks & With breaks \\
\hline & $P_{t}$ & $\begin{array}{c}-1.83^{* * *} \\
(0.41)\end{array}$ & \\
\hline & $P_{t}(1949-1994)$ & & $-1.79 * * *$ \\
\hline & & & $(0.40)$ \\
\hline & $P_{t}(1994-2013)$ & & $-1.77^{* * *}$ \\
\hline & & & $(0.39)$ \\
\hline$\tilde{\Xi}$ & Psubst $_{t}$ & $0.83^{* * *}$ & $0.82^{* * *}$ \\
\hline हृ & & $(0.27)$ & $(0.26)$ \\
\hline & $P x_{t}$ & $0.38^{*}$ & $0.38^{*}$ \\
\hline & & $(0.20)$ & $(0.21)$ \\
\hline & Investment $_{t}$ & $0.98^{* * *}$ & $0.10^{* * *}$ \\
\hline & & $(0.19)$ & $(0.21)$ \\
\hline & $T_{t}$ & $-0.062^{* * *}$ & $-0.62^{* * *}$ \\
\hline & & $(0.016)$ & $(0.017)$ \\
\hline & $P_{t}$ & $\begin{array}{l}0.38^{* * *} \\
(0.097)\end{array}$ & \\
\hline & $P_{t}(1949-1994)$ & & $\begin{array}{c}0.53 * * * \\
(0.16)\end{array}$ \\
\hline & $P_{t}(1994-2013)$ & & $0.53 * * *$ \\
\hline & & & $(0.18)$ \\
\hline & Wage in forestryt & $0.14^{* *}$ & $0.23^{* *}$ \\
\hline & & $(0.0645)$ & $(0.12)$ \\
\hline 형 & $i_{t}$ & $-0.030 * *$ & $-0.025 *$ \\
\hline$\stackrel{2}{\Xi}$ & & $(0.013)$ & $(0.015)$ \\
\hline & Penergy $_{t}$ & $-0.53^{* * *}$ & $-0.73 * * *$ \\
\hline & & $(0.17)$ & $(0.21)$ \\
\hline & Storm $_{t}$ & $0.079 * * *$ & $0.0746^{* * *}$ \\
\hline & & $(0.012)$ & $(0.014)$ \\
\hline & $D 1962_{t}$ & & $-0.16^{*}$ \\
\hline & & & $(0.092)$ \\
\hline & $D 2000_{t}$ & & $0.12^{*}$ \\
\hline & & & $(0.069)$ \\
\hline
\end{tabular}

Standard errors in parentheses

${ }^{*} p<0.1,{ }^{* *} p<0.05,{ }^{* * *} p<0.01$ 

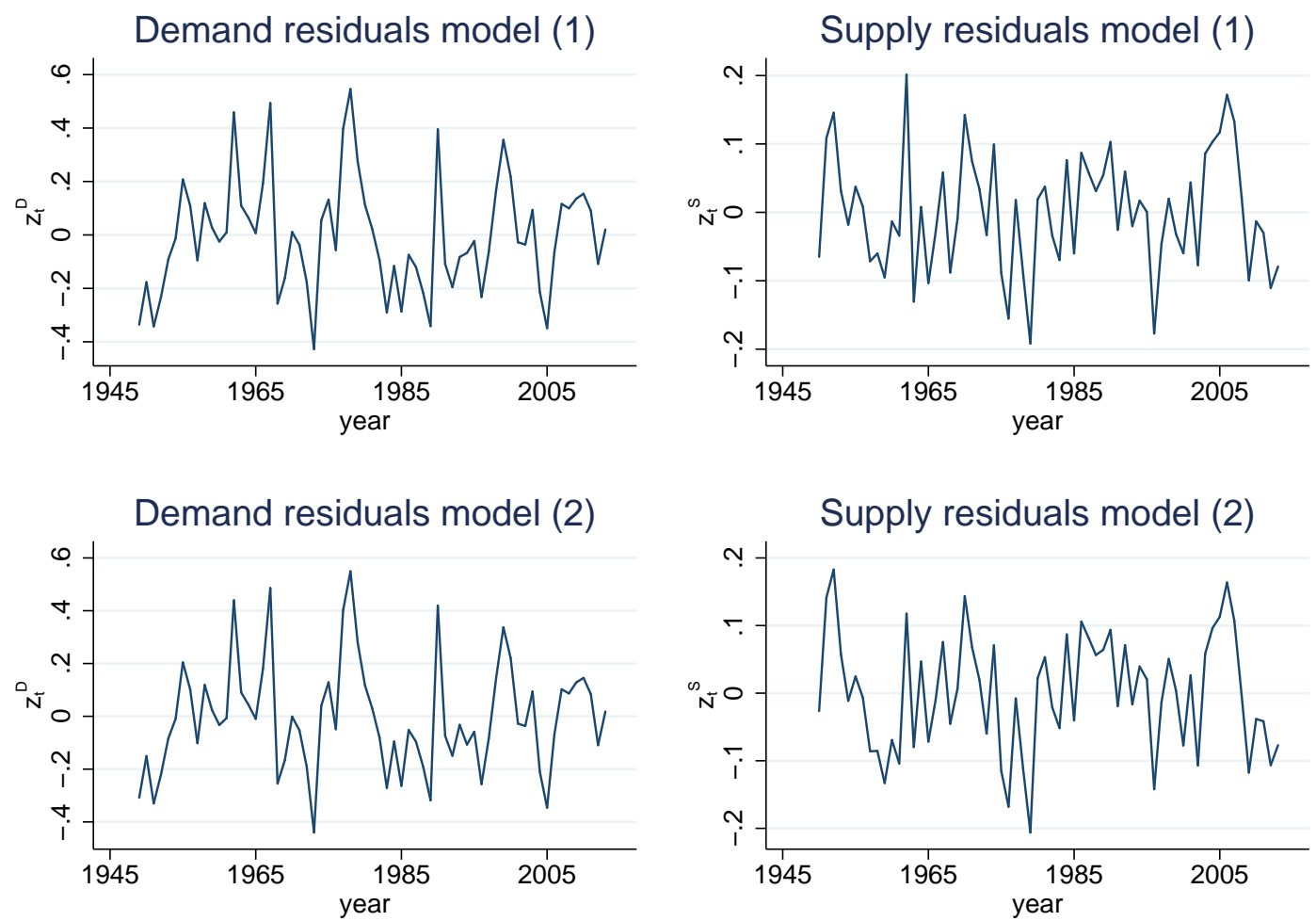

Figure A.1: Plots of the residuals

Table A.5: Post-estimation tests

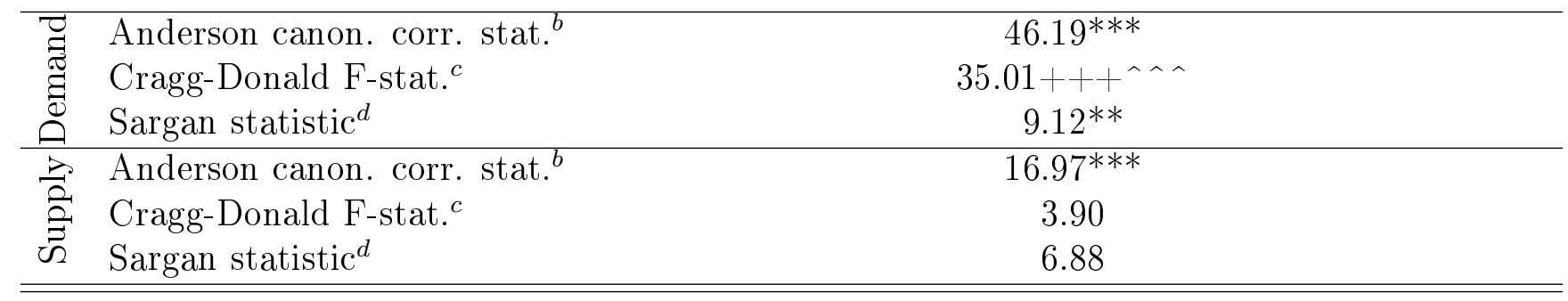

${ }^{*} p<0.1,{ }^{* *} p<0.05, * * * p<0.01$

$+20 \%$ maximal IV relative bias,$++10 \%$ maximal IV relative bias, $+++5 \%$ maximal IV relative bias

^ $20 \%$ maximal IV size, $\wedge^{\wedge} 15 \%$ maximal IV size, ${ }^{\wedge} \wedge$ 10\% maximal IV size

${ }^{b}$ Underidentification test (H0: Equations are underidentified)

${ }^{c}$ Weak identification test (Stock and Yogo, 2005)

${ }^{d}$ Overidentifying restrictions test (H0: instruments are valid and excluded instruments are correctly excluded)

\section{Forecasting}

Although forecasting is subject to the Lucas critique (Lucas, 1972) that agents anticipate changes rationally, it is possible to predict the dependent variable for out of the sample years and compare it to real values. To do so, we estimate our model ${ }^{25}$ again but alternatively drop the first (1950

${ }^{25}$ We choose the model without structural breaks, given the values of the BIC 
and 1951) and the last 2 years (2012 and 2013). We then predict years 1950, 1951 with equations 3 and 2012 and 2013 with equations 4:

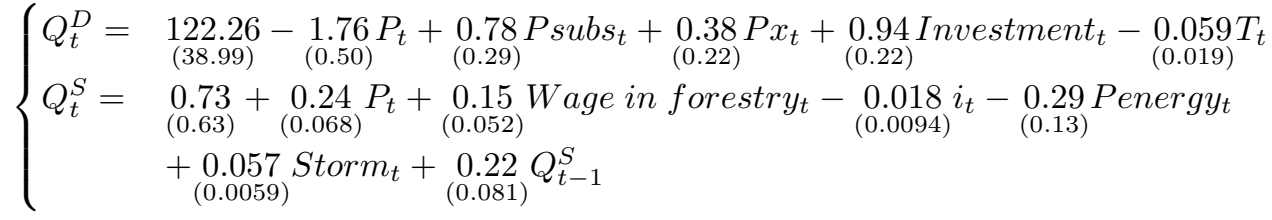

$$
\begin{aligned}
& \left\{\begin{aligned}
Q_{t}^{D}= & \underset{(33.73)}{133.16}-\underset{(0.44)}{1.89} P_{t}+\underset{(0.89)}{0.78 \text { Pubs }_{t}}+\underset{(0.22)}{0.39} \text { P }_{t}+\underset{(0.19)}{0.92 \text { Investment }_{t}-\underset{(0.016)}{0.064 T_{t}}} \\
Q_{t}^{S}= & \underset{(0.63)}{1.05}+\underset{(0.071)}{0.26} P_{t}+\underset{(0.050)}{0.11} \text { Wage in forestry } \\
& +\underset{(0.00095)}{0.057} \text { Storm }_{t}+\underset{(0.082)}{0.27} Q_{t-1}^{S}
\end{aligned}\right.
\end{aligned}
$$

Comparisons of the forecasts and the real values for the years 1950, 1951, 2012 and 2013 are presented in Table A.6. For the years under scrutiny, our model tends to better predict years that are after our sample than before our sample. For years 1950 and 1951, the mean absolute prediction error $(\Delta)$ is $28 \%$, while it is only $11 \%$ for years 2012 and 2013 . Generally, our model tends to overestimate the equilibrium quantity for these years.

Table A.6: Results of the simulations and real values

\begin{tabular}{ccccccc}
\hline & Equation & & $\begin{array}{c}\text { Prediction } \\
\left(\text { millions of } m^{3}\right)\end{array}$ & $\begin{array}{c}\text { Real value } \\
\left(\text { millions of } m^{3}\right)\end{array}$ & $\begin{array}{c}\Delta \\
\left(\text { millions of } m^{3}\right)\end{array}$ & $\begin{array}{c}\Delta \\
(\%)\end{array}$ \\
\hline \multirow{2}{*}{1950} & Demand & $Q^{D}$ & 2.40 & 1.74 & +0.66 & $+38 \%$ \\
& Supply & $Q^{S}$ & 1.86 & 1.74 & +0.12 & $+7 \%$ \\
\hline \multirow{2}{*}{1951} & Demand & $Q^{D}$ & 3.22 & 2.08 & +1.14 & $+55 \%$ \\
& Supply & $Q^{S}$ & 1.86 & 2.08 & -0.22 & $-11 \%$ \\
\hline \hline \multirow{2}{*}{2012} & Demand & $Q^{D}$ & 3.39 & 2.97 & +0.42 & $+14 \%$ \\
& Supply & $Q^{S}$ & 3.46 & 2.97 & +0.49 & $+16 \%$ \\
\hline \multirow{2}{*}{2013} & Demand & $Q^{D}$ & 3.01 & 2.97 & +0.04 & $+1 \%$ \\
& Supply & $Q^{S}$ & 3.37 & 2.97 & +0.40 & $+13 \%$ \\
\hline
\end{tabular}

